\title{
Response of understory vegetation over 10 years after thinning in an old-growth cedar and cypress plantation overgrazed by sika deer in eastern Japan
}

\author{
Atsushi Tamura* (1) and Masanobu Yamane
}

\begin{abstract}
Background: Forest management strategies such as thinning have long been used to enhance ecosystem functions, especially in plantations. Thinning in plantations with high deer density, however, may not yield a desired increase in understory vegetation because deer graze on germinating plants after thinning. Here, we examine the changes in understory vegetation after thinning in plantations that have been overgrazed by sika deer to provide insight into the effects of thinning on ecosystem functions such as soil conservation and biological diversity.

Methods: We conducted our survey in the Tanzawa Mountains of eastern Japan. We surveyed the change in understory vegetation within and outside of three deer exclosures on a single slope with three levels of understory vegetation cover: sparse ( $1 \%$, exclosure "US"), moderate (30\%, exclosure "MM"), and dense ( $80 \%$, exclosure "LD") over 10 years after a 30\% thinning of an old-growth cedar and cypress plantation which was overgrazed by sika deer.

Results: Understory vegetation cover, biomass and species richness increased within and outside the "US" and "MM" exclosures after thinning, and biomass was greater within than outside the exclosures at 10 years after thinning. Unpalatable species dominated both "US" and "MM" exclosures before thinning, and trees and shrubs dominated within the exclosures over time after thinning. In contrast, unpalatable, grazing-tolerant, perennial, and annual species increased outside the "US" and "MM" exclosures. No noticeable changes were observed within and outside the "LD" exclosure when compared with the "US" and "MM" exclosures.

Conclusions: Our results suggest that thinning a stand by $30 \%$ based on volume resulted in an increase in understory vegetation cover mainly composed of both unpalatable and grazing-tolerant species in a plantation forest where understory vegetation is sparse or moderate and sika deer density is high. We emphasize that establishing deer exclosures or controlling deer is essential to maintaining similar understory vegetation both within and outside exclosures.
\end{abstract}

Keywords: Biomass, Deer exclosure, Grazing-tolerant species, Understory cover, Unpalatable species

\footnotetext{
* Correspondence: tamura.7qh1@pref.kanagawa.jp

Division of Forest Research and Nature Restoration Planning, Kanagawa

Prefecture Natural Environment Conservation Center, 657 Nanasawa, Atsugi,

Kanagawa 243-0121, Japan
} 


\section{Background}

Forest management has been designed to enhance ecosystem functions such as biodiversity even in plantations in recent decades (Nagaike 2000; Hartley 2002; Carnus et al. 2006; Felton et al. 2010). Thinning as a management tool is believed to enhance understory vegetation (Hartley 2002; Carnus et al. 2006; Brockerhoff et al. 2008), to create a mix of various understory tree species or timber species (Carnus et al. 2006; Felton et al. 2010), to create snags, logs and other woody debris (Hartley 2002; Carnus et al. 2006) and to lengthen rotation periods (Hartley 2002; Carnus et al. 2006). Conifer plantations composed mainly of sugi (Cryptomeria japonica) and hinoki (Chamaecyparis obtusa) cover about 10 million ha or about $40 \%$ of the forested area in Japan (Japan Forestry Agency 2015). However, these include many inadequately-managed plantations (because of low wood prices) and this lack of management has created problems related to ecosystem functions such as soil conservation (Japan Forestry Agency 2015). Therefore, 35 prefectural governments have introduced new tax systems involving forest management that are designed to promote thinning of plantations (Japan Forestry Agency 2015).

Previous studies have demonstrated that thinning in plantations resulted in increases in understory vegetation cover, species richness (Thomas et al. 1999; Ares et al. 2010; Seiwa et al. 2012), and understory biomass (Ito 2006). Thinning also has the indirect potential to enhance ecosystem functions such as soil conservation (Miura et al. 2003; Fukata et al. 2006; Hiraoka et al. 2010). However, inadequate thinning produces only a limited increase in understory vegetation cover (Ito 2006).

It is most important to note, however, that thinning in plantations where deer density is high may not yield an increase in understory vegetation because deer feed on germinating plants after thinning. In recent decades there has been increasing recognition that deer can strongly influence forest ecosystems worldwide (Kirby 2001; Russell et al. 2001; Rooney and Waller 2003; Cote et al. 2004) and may cause serious damage to ecosystem functions such as biodiversity (Fuller 2001; Cote et al. 2004; Bressette et al. 2012) and soil conservation (Furusawa et al. 2003; Mohr et al. 2005; Wakahara et al. 2008). In Japanese plantations, some researchers have examined damage to trees such as the browsing of branches and leaves of juvenile trees (Koizumi 2002) and bark-stripping of adult trees by sika deer (Ueda et al. 2002; Jiang et al. 2005; Akashi and Terazawa 2005). The decline in understory vegetation in plantations inhabited by sika deer has received little attention, because it is often attributed to be a result of inadequate management rather than deer grazing per se. Some previous research has shown that thinning in plantations resulted in almost no increase in understory vegetation and this may be caused by grazing by sika deer.
Here, we examine the changes in understory vegetation after thinning in plantations heavily overgrazed by sika deer to provide insight into how heavy sika deer browsing may affect understory vegetation and thus ecosystem functions like soil conservation or biological diversity.

Our objective was to determine the response of understory vegetation quantity and quality to thinning in an old-growth plantation that was heavily grazed by sika deer. Specifically, we addressed the following questions: 1) did thinning (here, by $30 \%$ of stand volume) in an old-growth plantation increase understory vegetation cover, biomass, species richness, and species diversity under severe deer grazing pressure? Additionally, 2) if so, what are the types of species that benefited from thinning, such as palatable or grazing-tolerant species?

\section{Methods \\ Study area}

This study was conducted in Shimo-Dodaira, located northeast of Mount Tanzawa $\left(35^{\circ} 28^{\prime} 28.5^{\prime \prime} \mathrm{N}, 139^{\circ} 9^{\prime}\right.$ 46.8"E; $1567 \mathrm{~m}$ a.s.l.) in the Tanzawa Mountains in eastern Japan. Shimo-Dodaira is an east-facing landslide formation that ranges from 900 to $1056 \mathrm{~m}$ in height and $17^{\circ}$ to $23^{\circ}$ in inclination. The study site supports an oldgrowth cedar and cypress plantation (planted in 1911) with an area of 13.5 ha and includes some mixed broadleaved tree species such as Pterocarya rhoifolia, Pterostyrax hispida and Zelkova serrata (Table 1). Sharing a similar microtopography, the understory vegetation on the slopes was divided into three types based on the differences in understory vegetation cover. The upper, middle and lower slope exhibits sparse ("US"; 1\% cover), moderate ("MM"; $30 \%$ cover), and dense understory vegetation ("LD"; $80 \%$ cover), respectively. Prior to thinning in 2000, the understories of "US" and "MM" were initially composed of sparse Chloranthus serratus and Laportea bulbifera and that of "LD" was composed of dense Leucosceptrum japonicum. Thinning to $30 \%$ of stand volume was conducted from December 2000 to February 2001. A prior thinning had been conducted at the study site in 1974 and again in 1979. The density of sika deer was $9.2 \mathrm{~km}^{-2}$ in 1997 (Sika Deer Survey Group of Tanzawa-Oyama Comprehensive Research Team 1997), $30.0 \mathrm{~km}^{-2}$ in 2001, $20.8 \mathrm{~km}^{-2}$ in 2005 (Fujimori et al. 2013), and $16.5 \mathrm{~km}^{-2}$ in 2012 (Kanagawa Prefecture, unpublished results). Sika deer heavily grazed the understory vegetation during the entire study period.

Trees over $1.5 \mathrm{~m}$ in height were surveyed in a $50 \times 50$ $\mathrm{m}^{2}$ plot, which included each $10 \times 10-\mathrm{m}^{2}$ plot within and outside the exclosures with three different vegetation coverages $[1 \%$, sparse cover (US); $30 \%$, moderate cover (MM); 80\%, dense cover (LD)]. 
Table 1 Stand structure of the study site 4 years after thinning

\begin{tabular}{|c|c|c|c|c|c|c|c|c|c|c|c|c|}
\hline \multirow[t]{2}{*}{ Species name } & \multicolumn{3}{|c|}{ Density (number $\quad \mathrm{ha}^{-1}$ ) } & \multicolumn{3}{|c|}{ Mean DBH (cm) } & \multicolumn{3}{|c|}{ Mean Height (m) } & \multicolumn{3}{|c|}{ Basal area $\left(\mathrm{m}^{2} \mathrm{ha}^{-1}\right)$} \\
\hline & US & MM & LD & US & $\mathrm{MM}$ & LD & US & MM & LD & US & $\mathrm{MM}$ & LD \\
\hline Cryptomeria japonica & 84 & 116 & 220 & 41.2 & 51.2 & 44.7 & 22.4 & 24.9 & 23.2 & 13.5 & 28.5 & 43.3 \\
\hline Chamaecyparis obtusa & 176 & 96 & 44 & 28.9 & 40.3 & 34.2 & 17.6 & 22.8 & 21.1 & 16.5 & 14.9 & 5.5 \\
\hline Chamaecyparis pisifera & & & 12 & & & 34.0 & & & 21.7 & & & 1.6 \\
\hline Magnolia obovata & 52 & 20 & 8 & 29.1 & 26.0 & 26.0 & 19.1 & 19.0 & 16.6 & 4.9 & 1.5 & 0.6 \\
\hline Zelkova serrata & 8 & 12 & 28 & 32.5 & 54.3 & 35.6 & 19.9 & 24.9 & 21.5 & 1.1 & 3.4 & 3.6 \\
\hline Pterocarya rhoifolia & 16 & & & 58.0 & & & 23.3 & & & 5.4 & & \\
\hline Acer diabolicum & 4 & & & 23.0 & & & 22.6 & & & 0.3 & & \\
\hline Phellodendron amurense var. japonicum & 44 & & & 39.9 & & & 21.5 & & & 9.5 & & \\
\hline Styrax japonica & & & 4 & & & 11.0 & & & 4.9 & & & 0.1 \\
\hline Pterostyrax hispida & & & 8 & 59.7 & & 13.5 & 23.7 & & 10.4 & & & 0.3 \\
\hline Conifer trees & 260 & 212 & 276 & & & & & & & 30.0 & 43.4 & 50.4 \\
\hline broad-leaved trees & 124 & 32 & 48 & & & & & & & 21.1 & 4.9 & 4.7 \\
\hline Total & 384 & 244 & 324 & & & & & & & 51.1 & 48.3 & 55.0 \\
\hline
\end{tabular}

\section{Field surveys}

Before thinning in 2000 , three $10-\times 10-\mathrm{m}^{2}$ plots were established on "US", "MM" and "LD", one on each representative slope, respectively. After thinning in March 2001 , one deer exclosure $\left(10 \times 10 \mathrm{~m}^{2}, 1.8-\mathrm{m}\right.$ high and made of wire net with $10-\times 10-\mathrm{cm}^{2}$ mesh) was established on each plot; in addition, three control plots, which were the same size as the fenced plots, were set up, one outside each of the three exclosures but were not fenced. We established three $2-\times 8-\mathrm{m}^{2}$ sub-plots in each plot and divided each sub-plot into four $2-\times 2-\mathrm{m}^{2}$ quadrats in 2002 (12 quadrats for each plot).

Understory vegetation shorter than $1.5-\mathrm{m}$ high was investigated in each plot in 2000 and 2001 and in each $2-\times 2-\mathrm{m}^{2}$ quadrat from 2002 to 2005 and in 2011. The understory vegetation cover and cover classes of vascular plants within each plot or quadrat were recorded. Cover class of each species was determined using the Braun-Blanquet scale (Braun-Blanquet 1964). Scientific nomenclature for all plant species follows Flora Kanagawa 2001 (Flora Kanagawa Association 2001).

To estimate the understory biomass, five $1-\mathrm{m}^{2}$ subquadrats were harvested at each plot from 2000 to 2005 and 2010. Sub-quadrats were clipped so that each entire research quadrat would not be disturbed. Samples were oven-dried at $80^{\circ} \mathrm{C}$ for $48 \mathrm{~h}$ to obtain dry weight. To determine the light environment at $1-\mathrm{m}$ above ground in each plot, the relative photosynthetic photon flux density (rPPFD) was determined with two quantum sensors (MES-101; Koito-Kogyo, Tokyo, Japan) from 2000 to 2005 and in 2010.

\section{Data analysis}

Understory vegetation cover, biomass, species richness $\left(100 \mathrm{~m}^{-2}\right.$ and $\left.48 \mathrm{~m}^{-2}\right)$ and Shannon's diversity index $\left(H^{\prime}\right)$ were calculated for each plot. Relative dominance of several life forms [(tree, shrub, perennial, annual, and other (vine and bamboo)], and unpalatable, grazing-tolerant, and other species were calculated by summing the coverage values. Table 2 lists unpalatable and grazing-tolerant species. To classify the change in understory vegetation, detrended correspondence analysis (DCA) was conducted in the Vegan package of $\mathrm{R}$ ver. 3.0.3 ( $\mathrm{R}$ Development Core Team 2014) using average dominance based on coverage values for all plant species in every quadrat for each year.

\section{Results}

\section{Light environment}

The rPPFD of each plot before thinning was under $5 \%$, increased sharply to a maximum value at 1 or 2 years after thinning except outside the "US" exclosure, and then decreased to $6 \%$ or less at 10 years after thinning (Fig. 1a).

\section{Understory vegetation cover}

Understory vegetation cover within and outside the "US" and "MM" exclosures increased over time after thinning (Fig. 1b). The cover within the "US" and "MM" exclosures tended to be greater than outside the exclosures and the cover outside needed more than 5 years to equal that within the exclosures. The cover both within and outside the "LD" exclosure shifted from 60 to $100 \%$ over time after thinning. No difference in the cover between within and outside the exclosure was observed at 11 years after thinning in each plot. 
Table 2 List of species that are unpalatable and grazing tolerant to deer in study area

\begin{tabular}{|c|c|c|c|c|}
\hline Type & Species name & Family name & Life form & References \\
\hline \multirow[t]{17}{*}{ Unpalatable } & Dennstaedtia hirsuta & Dennstaedtiaceae & perennial & 1 \\
\hline & Dennstaedtia wilfordii & Dennstaedtiaceae & perennial & 6 \\
\hline & Stegnogramma pozoi subsp. mollissima & Thelypteridaceae & perennial & 1 \\
\hline & Chloranthus serratus & Chloranthaceae & perennial & 1,5 \\
\hline & Arisaema spp. & Araceae & perennial & 1,5 \\
\hline & Arisaema angustatum & Araceae & perennial & 1,5 \\
\hline & Arisaema nikoense & Araceae & perennial & 1,5 \\
\hline & Cocculus trilobus & Menispermaceae & vine & 1 \\
\hline & Boenninghausenia albiflora var. japonica & Rutaceae & perennial & 1,5 \\
\hline & Pterostyrax hispida & Styracaceae & tree & 4,5 \\
\hline & Cynoglossum asperrimum & Boraginaceae & perennial & 1 \\
\hline & Cynanchum caudatum var. tanzawamontanum & Apocynaceae & vine & 6 \\
\hline & Trachelospermum asiaticum & Apocynaceae & vine & 6 \\
\hline & Tubocapsicum anomalum & Solanaceae & perennial & 1 \\
\hline & Crassocephalum crepidioides & Asteraceae & perennial & 1 \\
\hline & Aster ageratoides var. ageratoides & Asteraceae & perennial & 3 \\
\hline & Ligularia dentata & Asteraceae & perennial & 2,5 \\
\hline \multirow[t]{16}{*}{ Grazing-tolerant } & Brachypodium sylvaticum & Poaceae & perennial & 5 \\
\hline & Calamagrostis hakonensis & Poaceae & perennial & 5 \\
\hline & Festuca parvigluma & Poaceae & perennial & 5 \\
\hline & Oplismenus undulatifolius & Poaceae & perennial & 5 \\
\hline & Microstegium japonicum & Poaceae & Annual & 5 \\
\hline & Microstegium vimineum & Poaceae & Annual & 5 \\
\hline & Sasa hayatae & Poaceae & bamboo & 6 \\
\hline & Persicaria debilis & Polygonaceae & Annual & 5 \\
\hline & Persicaria longiseta & Polygonaceae & Annual & 6 \\
\hline & Persicaria nepalensis & Polygonaceae & Annual & 6 \\
\hline & Persicaria posumbu & Polygonaceae & Annual & 5 \\
\hline & Pilea hamaoi & Urticaceae & Annual & 5 \\
\hline & Pilea japonica & Urticaceae & Annual & 5 \\
\hline & Clinopodium micranthum var. micranthum & Lamiaceae & perennial & 6 \\
\hline & Hydrocotyle yabei var. yabei & Apiaceae & perennial & 5 \\
\hline & Cirsium tenuipedunculatum & Asteraceae & perennial & 6 \\
\hline
\end{tabular}

1, Takatsuki (1989); 2, Hasegawa (2000); 3, Nomiya et al. (2003); 4, Ninomiya and Furubayashi (2003); 5, Tamura and Katsuyama (2007); 6, Tamura (personal observation)

\section{Understory biomass}

Understory biomass within and outside the "US" and "MM" exclosures tended to increase over time after thinning (Fig. 1c); yet, biomass was greater within than outside the exclosures at 10 years after thinning. Biomass outside the "US" and "MM" exclosures peaked at 5 years after thinning and then both these sites had the same amount of biomass at 10 years. Biomass both within and outside the "LD" exclosure tended to increase achieving a steady state at 1-3 years after thinning, and no difference in biomass was observed between within and outside the exclosure at 10 years after thinning (Fig. 1c).

\section{Understory species richness and diversity}

Species richness within and outside the "US" and "MM" exclosures tended to increase and achieved a steady state at 2-4 years after thinning (Fig. 1d) and decreased at 11 years after thinning. However, by 11 years after thinning it was greater in both plots than that before thinning. No difference in species richness was observed between within and outside the "MM" and "LD" 

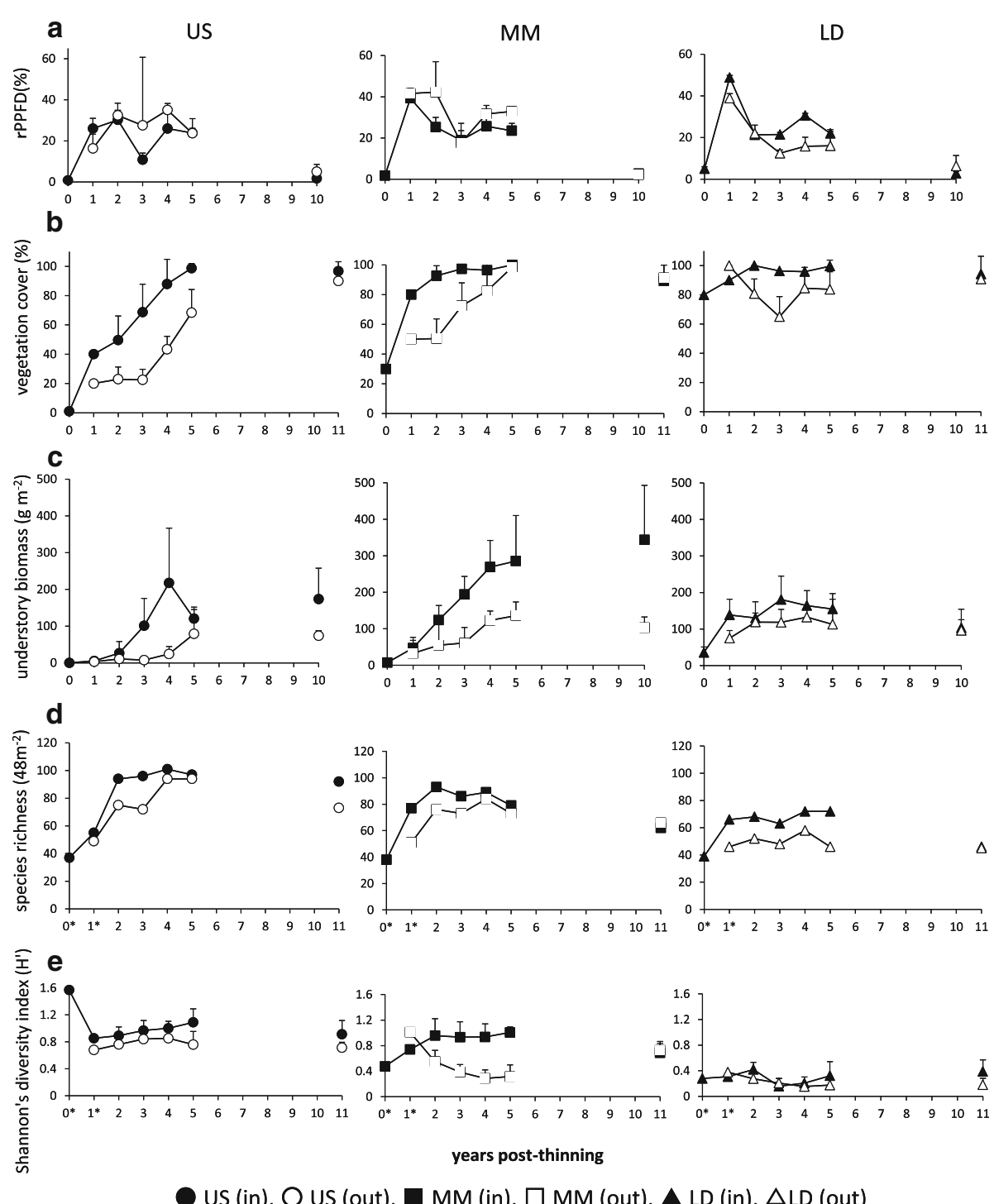

US (in), O US (out), $\boldsymbol{\square}$ MM (in), $\square \mathrm{MM}$ (out), $\boldsymbol{\Delta}$ LD (in), $\triangle \mathrm{LD}$ (out)

Fig. 1 Changes in light conditions and understory vegetation before and 10 or 11 years after thinning. Three different levels of vegetation cover were used: $1 \%$, sparse cover (US); 30\%, moderate cover (MM); $80 \%$, dense cover (LD). a rPPFD, b understory vegetation cover, c understory biomass, d species richness, and e Shannon's diversity index $\left(H^{\prime}\right)$; in, within the exclosure; out, outside the exclosure. ${ }^{*}$ denotes the value obtained from a $10 \times 10-m^{2}$ plot and not a $2 \times 2-m^{2}$ quadrat. Error bars indicate SD

exclosures at 11 years after thinning. Species richness both within and outside the "LD" exclosure shifted equally over time after thinning.

$H^{\prime}$ within the "US" and "MM" exclosures tended to be greater than those outside exclosures, and $\mathrm{H}^{\prime}$ both within and outside the "LD" exclosure remained the same over time after thinning (Fig. 1e).

\section{Understory species composition}

DCA ordination of all plant species data for every plot in each year showed that both "US" and "MM" were in the first quadrant before thinning; after thinning the plots within and outside of the "US" and "MM" exclosures shifted into the second and fourth quadrants over time (Fig. 2a). Both plots within and outside the "LD" exclosure almost remained near the boundary of the second and third quadrants over time before and after thinning. The first two axes accounted for 45.1 and $21.5 \%$ of total variance, respectively.

At the species level, grazing-tolerant Hydrocotyle yabei var. yabei and unpalatable C. serratus were on the edge of the first quadrant; L. japonicum was on the left side of the second quadrant; unpalatable Boenninghausenia albiflora var. japonica and P. hispida, and grazing-tolerant Cirsium 


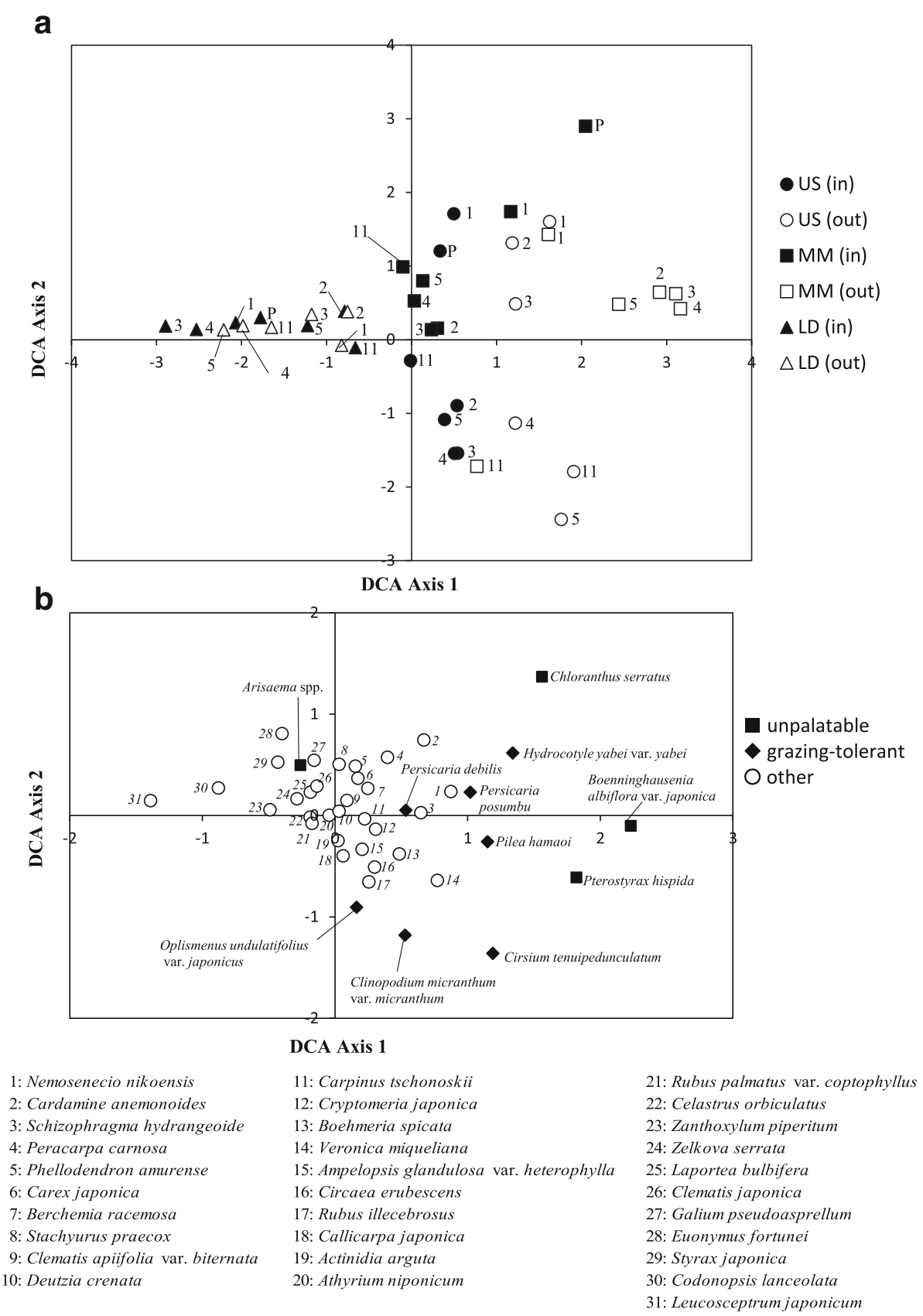

Fig. 2 Ordination by detrended correspondence analysis (DCA) based on the mean coverage of all species. Data are for every quadrat in each year. a Plot ordination. The first two axes accounted for $45.1 \%$ and $21.5 \%$ of the total variance, respectively. US, sparse cover (1\%); MM, moderate cover (30\%); $L D$, dense cover (80\%); in, within the exclosure; out, outside the exclosure; $P$, pre-thinning; numbers represent years after thinning. b Major species ordination; the 42 most frequent species are displayed in the figure

tenuipedunculatum were in the fourth quadrant; and shrubs such as Rubus palmatus var. coptophyllus were clustered together near the origin (Fig. 2b).

Coverage of trees and shrubs such as Deutzia crenata, Phellodendron amurense, $R$. palmatus var. coptophyllus and Stachyurus praecox increased after thinning within both the "US" and "MM" exclosures (see Additional file 1).
It is important to note that outside the "US" and "MM" exclosures, unpalatable species such as B. albiflora var. japonica and $P$. hispida, grazing-tolerant species such as C. tenuipedunculatum and $H$. yabei var. yabei increased after thinning. L. japonicum was abundant during the course of the study period both within and outside the "LD" exclosure. 
Relative dominance of understory vegetation

The relative dominance of woody plants, both trees and shrubs, increased over time after thinning within all three exclosures, and was especially notable within the "US" and "MM" exclosures (Fig. 3). Outside the "US" and "MM" exclosures, the relative dominance of annual species increased 2 years after thinning and occupied $15-18 \%$ of the coverage 11 years after thinning (Fig. 3). The area outside of the "LD" exclosure was dominated by perennial species throughout the study period.

Note that within both the "US" and "MM" exclosures the relative dominance of both palatable and grazingtolerant species decreased over time after thinning (Fig. 4). In contrast, outside both of these exclosures, these species remained dominant over time. Within and outside the "LD" exclosure, the relative dominance remained unchanged during the study period and was dominated by other species such as L. japonicum.

\section{Discussion}

The results obtained outside the "US" and "MM" exclosures showed that understory vegetation cover, biomass and species richness of this old-growth plantation increased over time after thinning, even under severe deer grazing pressure. These measurements were greater 10 or 11 years after thinning than before and just after thinning in these plots. However, understory biomass at 10 years after thinning outside the "US" and "MM" exclosures were approximately one-half and one-third of those within the exclosures, respectively indicating that heavy sika deer browsing can indeed have dramatic effects. Furthermore, understory vegetation outside the "US" and "MM" exclosures was dominated by perennial, annual, unpalatable, and grazing-tolerant species, whereas understory vegetation within the "US" and "MM" exclosures was dominated by woody plants (trees and shrubs) over time. Overall, these results demonstrate that thinning led to increased understory vegetation in this old-growth plantation heavily grazed by sika deer, and that most understory vegetation was composed of perennial, annual, unpalatable, and grazing-tolerant species.

Few data are available from previous studies related to the change in understory vegetation after thinning in old-growth plantations and under severe sika deer grazing pressure, although studies had been conducted on young or mature plantations with no or few deer (Ito 2006; Noguchi et al. 2009). Outside Japan, several studies that addressed the effects of thinning on understory vegetation have been conducted in young plantations where thinning was implemented to increase food biomass for deer that would be hunted (Sullivan et al. 2007, 2010; Cole et al. 2010). In general, understory vegetation declines with crown canopy closure in young or mature plantations, even if it initially increased after thinning (Kiyono 1990; Suzuki et al. 2005). In our study, light conditions (rPPFD) at 10 years after thinning were similar to those before thinning; however, understory vegetation cover, biomass, and species richness at 10 or

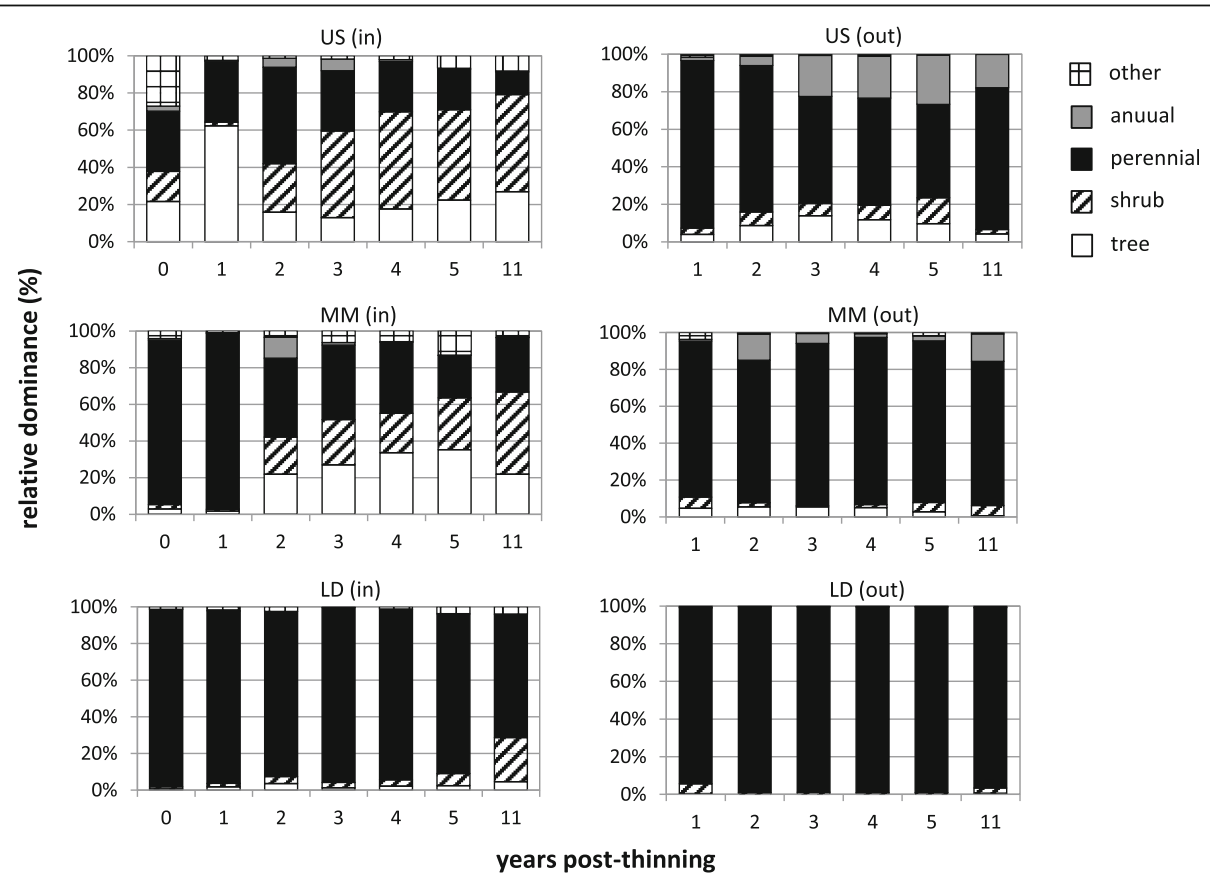

Fig. 3 Relative dominance changes of life forms in vegetation cover before and after thinning. Three different levels of vegetation cover vegetation cover were used: US, sparse cover (1\%); MM, moderate cover (30\%); LD, dense cover (80\%); in, within the exclosure; out, outside the exclosure 


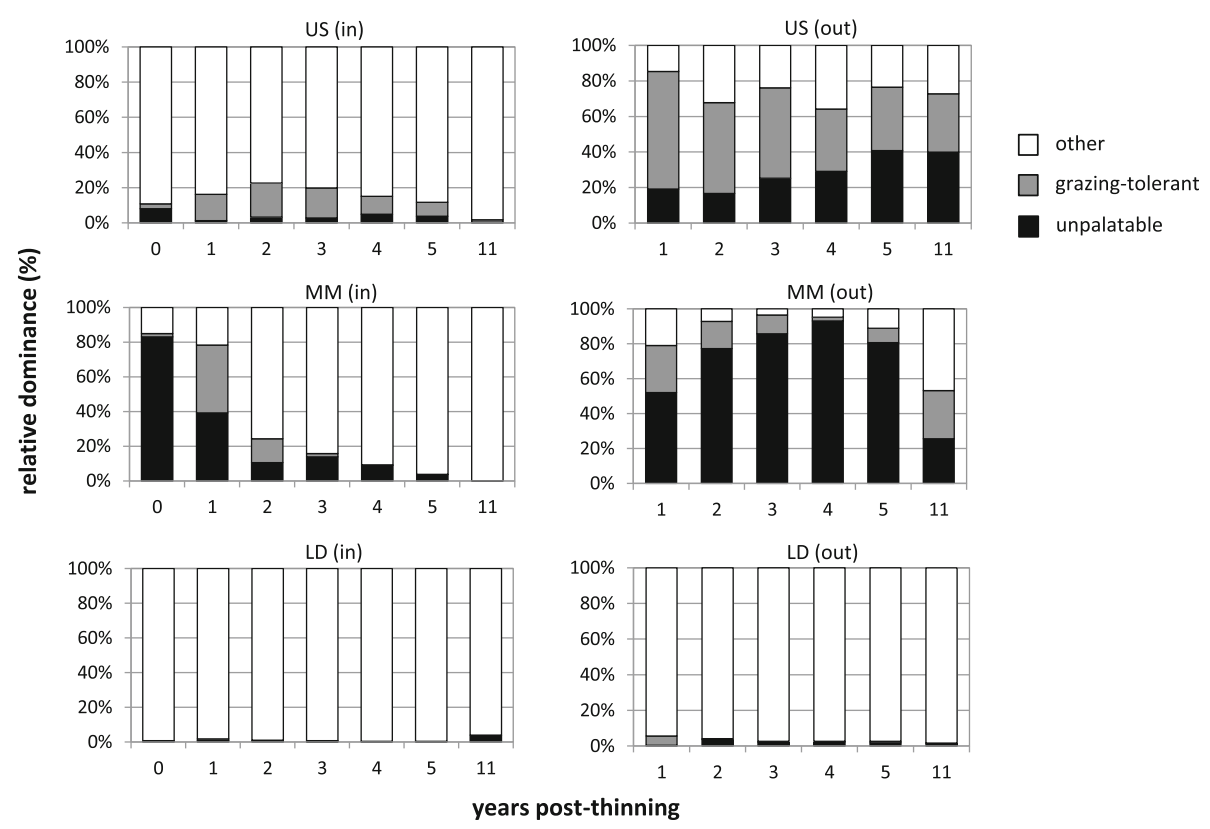

Fig. 4 Relative dominance changes in unpalatable and grazing-tolerant species in vegetation cover. Data represent before and after thinning in three different levels of vegetation cover: US, sparse cover (1\%); MM, moderate cover (30\%); LD, dense cover (80\%); in, within the exclosure; out, outside the exclosure

11 years after thinning were greater than before thinning even under severe deer grazing pressure, and understory vegetation cover and biomass seemed to have plateaued. Our study also revealed that the tree cover increased within but not outside the exclosures. Additionally, Tamura (2014), who studied regenerated trees at the same site, revealed that species richness was lower and fewer trees regenerated outside the exclosures compared to within the exclosures.

The difference in the response of understory vegetation to thinning among the three types of plots analyzed here indicate that understory vegetation conditions before thinning may affect the changes observed after thinning. Understory vegetation responses in the "LD" exclosure were slightly different from those in "US" and "MM" exclosures. Understory cover, biomass, and species richness both within and outside the "US" and "MM" exclosures increased over time after thinning. However, the changes in the "LD" exclosure were limited when compared with those observed within and outside the "US" and "MM" exclosures. In addition, understory species composition in "LD" was also different from that of the "US" and "MM" exclosures. This occurred as a result of the density of L. japonicum, a perennial tall herb, before thinning. The species was grazed by sika deer during late summer, but did not disappear (Tamura, personal observation), potentially because it can multiply by rhizomes. Previous studies have reported that dense understory vegetation prevents plant species from invading and growing (Royo and Carson 2006; Tamura 2014).
In our study we suggest that $L$. japonicum may have prevented the invasion of other species.

The different ratios of unpalatable to grazing-tolerant species outside the "US" and "MM" exclosures may also be attributable to the difference of understory vegetation before thinning, because fewer unpalatable species occurred outside the "US" exclosure when compared with species growing outside the "MM" exclosure. These results indicated that the composition of unpalatable and grazing-tolerant species before thinning likely influenced the composition and structure of understory vegetation after thinning under the severe deer grazing pressure in our study. Noguchi et al. (2009) also found that understory vegetation conditions before thinning affects the developmental of understory vegetation after thinning.

Understory vegetation outside the exclosures would probably remain consistent, such as with a high proportion of perennial or unpalatable species, even if sika deer density decreased. This would be expected to occur because, in general, the species composition of forest vegetation changes if deer have been overgrazing, and unpalatable and grazing-tolerant species increase (Husheer et al. 2003; Rooney and Waller 2003). The density of unpalatable species rarely decreases once they have become well established (Kirby 2001; Husheer et al. 2003). Dense understory vegetation, even if palatable, prevents other plant species from invading and growing, and diminishes tree generation, thus altering the rate and direction of forest succession (Royo and Carson 2006). In our study, understory vegetation outside the "US" and 
"MM" exclosures was mainly composed of unpalatable B. albiflora var. japonica 11 years after thinning, and understory vegetation of "LD" was composed of $L$. japonicum during the course of study period. However, at 10 years after thinning the light conditions (rPPFD) had decreased to the same level as that before thinning. Note that while B. albiflora var. japonica and L. japonicum are forest floor species (Flora Kanagawa Association 2001) and can grow under low rPPFD, in contrast, we predict that annual or small perennial grazing-tolerant species would decline if there were a substantial expansion of tall perennial species such as B. albiflora var. japonica and L. japonicum.

Our study was conducted in a single old-growth plantation with three different levels of understory vegetation cover, so one must be cautious in extrapolating our conclusions to other situations even if there is similarly severe sika deer grazing pressure. Nevertheless, our results which reveal that understory vegetation cover, biomass, and species richness increased after thinning even under severe deer grazing pressure represents a new finding, and one which we hope will be studied further, especially as this relates to factors that maintain important ecosystem functions like soil conservation.

\section{Conclusions}

Thinning in old-growth conifer plantations can increase in understory vegetation cover that is mainly composed of unpalatable and grazing-tolerant species in a plantation forest where understory vegetation is sparse or moderate and sika deer density is high. We emphasize that establishing deer exclosures or controlling deer is essential to miantaining similar understory vegetation both within and outside exclosures.

\section{Additional file}

Additional file 1: Change in the mean cover (\%) of major species at pre-thinning and 1,3,5, and 11 years post-thinning. Species that had frequencies over $60 \%$ in the $122 \times 2$-m2 plots, and palatable and grazing-tolerant are shown. US, sparse cover (1\%); MM, moderate cover (30\%); LD, dense cover (80\%); in, inside the exclosure; out, outside the exclosure; UP, unpalatable species; GT, grazing-tolerant species. (DOCX 73 kb)

\section{Abbreviations}

ANOVA: Analysis of variance; DCA: Detrended correspondence analysis; LD: $80 \%$, dense understory vegetation cover; MM: 30\%, moderate understory vegetation cover; US: $1 \%$, sparse understory vegetation cover

\section{Acknowledgments}

We thank Y. Mashino and M. Ohya for establishing the study site; M. Mitsuhashi, A. Irino, N. Yoshida, T. Kobayashi, M. Maki, N. Nakanishi, M. Nakamura, Y. Takaishi, Y. Honda, H. Nakayama, S. Yamamoto, N. Nagasawa, M. Murakami, K. Takahashi, K. Miki, T. Ichikawa, and Y. Tokue of Nippon Koei for field assistance during the course of our study; and M. Chuman for assisting with DCA. We also thank Handling Editor and two anonymous reviewers for commenting on the manuscript.

\section{Availability of data and materials}

The datasets supporting the conclusions of this article are included within the articles.

\section{Authors' contributions}

AT was involved in all parts of this research from the study design to the manuscript writing. MY provided critical revisions and final approval of the article. Both authors read and approved the final manuscript.

\section{Competing interests}

The authors declare that they have no competing interests.

\section{Consent for publication}

Not applicable.

\section{Ethics approval and consent to participate}

Not applicable.

Received: 22 September 2016 Accepted: 16 December 2016

Published online: 03 January 2017

\section{References}

Akashi N, Terazawa K (2005) Bark stripping damage to conifer plantations in relation to the abundance of sika deer in Hokkaido, Japan. For Ecol Manage 208:77-83

Ares A, Neill AR, Puettmann KJ (2010) Understory abundance, species diversity and functional attribute response to thinning in coniferous stands. For Ecol Manage 260:1104-1113

Braun-Blanquet J (1964) Pflanzensoziologie. Springer, Berlin Heidelberg New York Bressette JW, Beck H, Beauchamp VB (2012) Beyond the browse line: complex cascade effects mediated by white-tailed deer. Oikos 121:1749-1760

Brockerhoff EG, Jactel H, Parrotta JA, Quine CP, Sayer J (2008) Plantation forests and biodiversity: oxymoron or opportunity? Biodivers Conserv 17:925-951

Carnus JM, Parrotta J, Brockerhoff E, Arbez M, Jactel H, Kremer A, Lamb D, O'Hara K, Walters B (2006) Planted forests and biodiversity. J Forestry 104:65-77

Cole EC, Hanley TA, Newton M (2010) Influence of precommercial thinning on understory vegetation of young-growth Sitka spruce forests in southeastern Alaska. Can J For Res 40:619-628

Cote SD, Rooney TP, Tremblay J, Dussault C, Waller DM (2004) Ecological impacts of deer overabundance. Annu Rev Ecol Evol Syst 35:113-147

Felton A, Lindbladh M, Brunet J, Fritz O (2010) Replacing coniferous monocultures with mixed-species production stands: an assessment of the potential benefits for forest biodiversity in northern Europe. For Ecol Manage 260:939-947

Flora Kanagawa Association (2001) Flora of Kanagawa 2001. Kanagawa Prefectural Museum of Natural History, Odawara (in Japanese)

Fujimori H, Suetsugu K, Ikeya S, Kobayashi T, Nagata K, Habuto H, Kisanuki K (2013) Populations density of sika deer (Cervus nippon) surveyed by block count method within the planning period of the Second Sika deer Management Plan in Kanagawa Prefecture. Bull Kanagawa Prefect Nat Environ Conserv Cent 11:27-36 (in Japanese)

Fukata H, Watanabe N, Kajihara N, Tsukamoto J (2006) Dynamics of undergrowth and its application to vegetation control of planted Chamaecyparis obtusa Endl. forests with special reference to mitigation of surface soil loss. J Jpn For Res 88:231-239 (in Japanese with English abstract)

Fuller RJ (2001) Responses of woodland birds to increasing numbers of deer: a review of evidence and mechanisms. Forestry 74:289-298

Furusawa H, Miyanishi H, Kaneko S, Hino T (2003) Movement of soil and litter on the floor of a temperate mixed forest with an impoverished understory grazed by deer (Cervus nippon centralis Temminck). J Jpn For Soc 85:318-325 (in Japanese with English abstract)

Hartley MJ (2002) Rationale and methods for conserving biodiversity in plantation forests. For Ecol Manage 155:81-95

Hasegawa J (2000) Changes of vegetation by sika deer grazing on Mt. NikkoShirane, Central Japan. J Phytogeogr Taxon 48:47-57 (in Japanese with English abstract)

Hiraoka M, Onda Y, Kato H, Mizugaki S, Gomi T, Nanko K (2010) Effects of understory vegetation on infiltration capacity in Japanese cypress plantation. J Jpn For Soc 92:145-150 (in Japanese with English abstract) 
Husheer SH, Coomes DA, Robertson AW (2003) Long term influences of introduced deer on the composition and structure of New Zealand Nothofagus forests. For Ecol Manage 181:99-117

Ito $\mathrm{H}$ (2006) Changes in undergrowth after thinning in a Cryptomeria japonica plantation in the suburbs of Kyoto City. Appl For Sci 15:83-86 (in Japanese)

Japan Forestry Agency (2015) Annual report on forest and forestry in Japan, Fiscal Year 2014. Forestry Agency, Ministry of Agriculture, Forestry and Fisheries, Tokyo

Jiang Z, Ueda H, Kitahara M, Imaki H (2005) Bark stripping by sika deer on veitch fir related to stand age, bark nutrition, and season in northern Mount Fuji district, central Japan. J For Res 10:359-365

Kirby KJ (2001) The impact of deer on the ground flora of British broadleaved woodland. Forestry 74:219-229

Kiyono Y (1990) Dynamics and control of understories in Chamaecyparis obtusa plantations. Bull For For Prod Res Inst 359:1-122 (in Japanese with English abstract)

Koizumi T (2002) Current status of forest damage by sika deer in Kyushu. Kyusyu J For Res 55:162-165 (in Japanese with English abstract)

Miura S, Yoshinaga S, Yamada T (2003) Protective effect of floor cover against soil erosion on steep slopes forested with Chamaecyparis obtusa (hinoki) and other species. J For Res 8:27-35

Mohr D, Cohnstaedt LW, Topp W (2005) Wild boar and red deer affest soil nutrients and soil biota in steep oak stands of the Eifel. Soil Biol Biochem 37:693-700

Nagaike T (2000) A review of ecological studies on plant species diversity in plantation ecosystems. J Jpn For Soc 82:407-416 (in Japanese with English abstract)

Ninomiya S, Furubayashi K (2003) Spatial structure and regeneration of beech forest affected by overbrowsing by sika deer (Cervus nippon). Wildl Conserv Jpn 8:63-77 (in Japanese with English abstract)

Noguchi M, Sakai A, Okuda S, Inagaki Y, Fukata H (2009) Six-year responses of understory vegetation to thinning in hinoki cypress plantations in Shikoku Island, Japan. Jpn J For Environ 51:127-136 (in Japanese with English abstract)

Nomiya H, Suzuki W, Kanazashi T, Shibata M, Tanaka H, Nakashizuka T (2003) The response of forest floor vegetation and tree regeneration to deer exclusion and disturbance in a riparian deciduous forest, central Japan. Plant Ecol 164: 263-276

R Development Core Team (2014) R: A language and environment for statistical computing. R Foundation for Statistical Computing, Vienna, http://www.rproject.org/

Rooney TP, Waller DM (2003) Direct and indirect effects of white-tailed deer in forest ecosystems. For Ecol Manage 181:165-176

Royo AA, Carson WP (2006) On the formation of dense understory layers in forests worldwide: consequences and implications for forest dynamics, biodiversity, and succession. Can J For Res 36:1345-1362

Russell FL, Zippin DB, Fowler NL (2001) Effects of White-tailed deer (Odocoileus virginianus) on plants, plant populations and communities: A review. Am Midl Nat 146:1-26

Seiwa K, Eto Y, Hishita M, Masaka K (2012) Effects of thinning intensity on species diversity and timber production in a conifer (Cryptomeria japonica) plantation in Japan. J For Res 17:468-478

Sika Deer Survey Group of Tanzawa-Oyama Comprehensive Research Team (1997) Result of sika deer density on Tanzawa-Oyama game reserve. In: Tanzawa-Oyama Comprehensive Research Group (eds) Additional report of the scientific research on the Tanzawa Mountains. Yokohama: Kanagawa Prefecture; pp 1-16 (in Japanese; the title was translated by the author of the present study)

Sullivan TP, Sullivan DS, Lindgren PMF, Ransome DB (2007) Long-term responses of ecosystem components to stand thinning in young lodgepole pine forest. IV. Relative habitat use by mammalian herbivores. For Ecol Manage 240:32-41

Sullivan TP, Sullivan DS, Lindgren PMF, Ransome DB (2010) Long-term responses of mammalian herbivores to stand thinning and fertilization in young lodgepole pine (Pinus contorta var. latifolia) forest. Can J For Res 40:2302-2312

Suzuki W, Suzaki T, Okumura T, Ikeda S (2005) Aging-induced development patterns of Chamaecyparis obtusa plantations. J Jpn For Soc 87:27-35 (in Japanese with English abstract)

Takatsuki S (1989) Effects of deer on plants and plant communities. Jpn J Ecol 39: 67-80 (in Japanese with English abstract)

Tamura A (2014) Effect of difference of floor vegetation cover on regeneration of trees on an old-growth Cedar and Cypress plantation. J Jpn For Soc 96:333341 (in Japanese with English abstract)
Tamura A, Katsuyama T (2007) Difference of stand structure and floor vegetation on the eastern and western Tanzawa Mountains suffered different deer grazing pressure. In: The Research Group of the Tanzawa Mountains (eds) Results of the Scientific Research on the Tanzawa Mountains. Hiraoka Environmental Science Laboratory, Sagamihara, pp 101-118 (in Japanese; the title was translated by the author of the present study)

Thomas SC, Halpern CB, Falk DA, Liguori DA, Austin KA (1999) Plant diversity in managed forests: understory responses to thinning and fertilization. Ecol Appl 9:864-879

Ueda H, Takatsuki S, Takahashi T (2002) Bark stripping of hinoki cypress by sika deer in relation to snow cover and food availability on Mt. Takahara, central Japan. Ecol Res 17:545-551

Wakahara T, Ishikawa Y, Shiraki K, Toda H, Miya T, Kataoka F, Suzuki M, Uchiyama Y (2008) Seasonal changes in the amount of litter layer and soil erosion in the forest floor: An impoverished understory by deer impact at Doudaira, Tanzawa Mountains. J Jpn For Soc 90:378-385 (in Japanese with English abstract)

\section{Submit your manuscript to a SpringerOpen ${ }^{\mathcal{O}}$ journal and benefit from:}

- Convenient online submission

- Rigorous peer review

- Immediate publication on acceptance

- Open access: articles freely available online

- High visibility within the field

- Retaining the copyright to your article

Submit your next manuscript at $>$ springeropen.com 